\title{
Development Research and Action: Four Approaches
}

\author{
Barbara Harriss-White
}

\begin{abstract}
I was honoured to be invited to speak at the IDS fortieth anniversary conference. As many of you will know, I have long had a close association with IDS, although I would not consider myself to be an 'IDS person'. Twenty per cent of my working life has been spent in South Asia and the rest of my intellectual journey has been in Cambridge, the University of East Anglia, the London School of Hygiene and Tropical Medicine, and now Oxford. My 'development studies' have been forged through the geography of South Asia, agricultural science, agricultural economics, development economics, nutrition, anthropology and politics. Starting out in development, I was certainly an IDS wannabe and later on I became an IDS spouse (there should have been a Roundtable for them!). ${ }^{1}$ However, although in practice my connection was social, IDS ideas were essential to my intellectual formation.
\end{abstract}

While others have talked about the grand narratives that IDS has developed and propagated worldwide, I want to pay homage to the research which was important to my own education in development. At the outset there was Michael Lipton's work on the logic of peasant agriculture, on technical change and on grain storage losses, which intersected with my research on food-grain markets; Robert Chambers' early work on rural development management, seasonality and water management; the late Biplab Dasgupta's writing on inter-village variation in the IDS village studies project; Kate Young's pioneering activist-research on gender; Colin Leys and later Robert Wade who opened up the whole question of corruption long before it became intertwined with 'good governance'; the late Bernard Schaffer, who I think was Foucauldian before Foucault's work had been translated, and who as early as 1974 dissected the linear model of policy that John Humphrey and Mike Edwards critically invoked here; Robin Luckham, who worked with Yash Ghai and Frances Snyder to produce the reader on law and development which came out just as policy fashions changed in the late 1970s but which is still a definitive compendium on law, policy and development; and Mick Moore whom I have to thank not only for his brilliant book on peasant politics in Sri Lanka but for having been a matchmaker and giving me nine very happy years. All their research flourished alongside the celebrated work on redistribution with growth and basic needs.

The contributions I list are theoretically diverse but they have been leading ideas. Right from its inception, IDS was deeply involved in theory-building, particularly in institutional macroeconomics, development economics and the critique of modernisation theory. IDS also negotiated - mainly critically but sometimes promotively - what was to many people the unforeseen swing towards the ideas of Polanyi (i.e. that economies are embedded in society and culture), which has assaulted the very idea of development and the need for special theory. Since that assault in the last quarter century we have engaged with rational choice theory and neoclassical institutional economics. We have also seen a proliferation of eclecticism and hyper-empiricism and have negotiated the influence of postmodernism: the study of text and words rather than action on the ground.

IDS40 searches for 'solutions' to 'make a difference' presupposing not only problems but also a prior understanding of the causes of those problems; so I wish to address the same theme as Mike Edwards, but from a slightly different angle. Using the Roundtables, I will explore the production of knowledge about development. The Roundtables are a significant achievement and IDS has been generous in making them a public good. In his Roundtable overview paper, Lawrence Haddad focused on Africa, so I will focus on the content of the South Asian feedback - 20 per cent of the world's population but only 5 per cent of 
Table 1 The Divison of Sociological Labour

\begin{tabular}{lll}
\hline & Academic audience & Non-academic audience \\
\hline Instrumental knowledge & Professional Sociology & Policy Sociology \\
- Knowledge & Theoretical/empirical & Concrete \\
- Truth & Correspondence & Pragmatic \\
- Legitimacy & Scientific norms & Effectiveness \\
- Pccountability & Peers & Clients/patrons \\
- Pathology & Self-referentiality & Servility \\
- Politics & Professional self-interest & Policy intervention \\
\hline
\end{tabular}

\section{Reflexive knowledge}

- Knowledge

- Truth

- Legitimacy

- Accountability

- Pathology

- Politics

\section{Critical Sociology}

Foundational

Normative

Moral vision

Critical intellectuals

Dogmatism

Internal debate

\section{Public Sociology}

Communicative

Consensus

Relevance

Designated publics

Faddishness

Public dialogue

Source Burawoy (2005). (Reproduced with permission.)

Roundtable participants. I will also borrow, as Mike Edwards did, from Michael Burawoy. After his important American Sociological Association presidential address, entitled 'For a Public Sociology', Burawoy proceeded to classify the ways in which knowledge in sociology is produced (Burawoy 2005). He distinguished the production of two kinds of knowledge, instrumental and reflexive, inside and outside the academy, making a two-by-two table with four cells (see Table 1). Inside the academy instrumental knowledge, the vast bulk of knowledge production in social sciences is professional knowledge. Outside the academy it is policy knowledge. Reflexive knowledge inside the academy is termed 'critical' (sometimes Burawoy refers to it as 'historical knowledge') and that destined for outside is identified as 'public knowledge'.

Mike Edwards made a very powerful case for public knowledge in development studies, but in fact there are four ways to make a difference.

First, through instrumental knowledge inside the profession. Most of the Roundtables produced a long list of themes in development studies which they felt urgently needed research. Every plenary speaker produced a list. Let us briefly examine the list from South Asia. It emphasises human security and contains suggestions about research into the relationships between economic development and military conflict, about the militarisation of development and the developmentisation of war. It also stresses themes of migration, identity and culture, with strong pleas for more research on ethnicity and gender (supplementing Joanna Kerr's case for religion, inequality, poverty and gender). Bangladesh made strong justifications not only for the study of 'de-development' (the systematic study of negative growth) but also for studies of the chaos which urban development has become; the agrarian crisis; the impact on the agrarian sector of jobless growth and a Gershenkron-style revisiting of the domestic ownership of the process of industrialisation, a revisiting of state-directed development and of the pathologies of tax evasion and avoidance which deprive the state of the resources it needs.

Now this is not a foreign-aid-driven research agenda, it is completely home-produced in South 
Asia. It does not mention foreign aid. Other things that are not mentioned are quite striking. HIV and AIDS (while raised in the IDS40 conference) is absent - while we now know that South Asia is the global epicentre of HIV-positive people. Also conspicuous by its absence was the powerful suggestion which came from IDS and suggested the need for an Asian Drivers project concerned with the influence of South Asia and East Asia on the rest of the world.

What is most striking about the lists, however, is that these are themes in search of theories. Development studies is increasingly defining itself in relation to policy so that the boundary between Michael Burawoy's two top cells is porous. And it is the impetus coming from policy that makes us define development problems as themes rather than as problems for theory.

Lawrence Haddad called for a new kind of development studies. Dudley Seers also called for it quite a long time ago, insisting on the value of rigorous comparisons throughout the world. Social policy was used as an example, where a method from development studies would require the expert comparison of - say - Ghana and Sweden. It followed that if this were a good way to study social policy (which is certainly the way the Chinese do it) then what space would be left for the study of development? Do we need the professional field of development? Seers argued - and I agree with him that development studies is still needed for its comparative approach, for its interpretive work, for the exploration and the negotiation of interdisciplinarity. Professional 'development studies' is itself a solution to problems generated by the disciplinary study of development.

Turning to instrumental research for policy (the second cell in the table) one very salient fact about IDS is that in 1997, despite public outcry, IDS had its corefunding withdrawn - so that for almost a decade it has had to define itself through research which was outside-funded and driven by policy concerns. In his Roundtable overview (this IDS Bulletin) Lawrence Haddad discusses development as 'human behaviour in an economic policy context'. He says that 'it's a buyer's market' and the buyers are banks, the UN, aid agencies and multinational corporations. The Sri Lanka Roundtable called for more research into the private sector, even on the defence sector. These sectors affect what is 'bought'.
A great range of interests require policy inputs from us as professionals. Two experts on aid (Baroness Amos and Gordon Conway) contributed to IDS40 and provided a list of current priorities. This list is different from the given at the Queen Elizabeth House (QEH) fiftieth anniversary conference in 2005. The lists from the aid policy community are not necessarily very stable and I want to make three points about policy research.

First there is an unavoidable tension, involving 'trusteeship, between the ambition to steer and to influence those who commission research but without being neocolonial (there was considerable comment about this danger from the Roundtables), and without stifling activity in the other cells of the matrix of knowledge production. All means of production of knowledge in development require outside funds because travel is usually necessary to them. Yet we must not also fall into the trap of making research fundable by depoliticising it - of which there were illustrations in the Roundtable reports. For example China and India were said to offer lessons for the rest of the world in terms of the 'correct sequencing of growth and openness'. If this sort of depoliticisation is unavoidable, as part of the policy research cell, it is all the more vital that there is a space for critical research to reflect on it.

A second point about policy research is that there is a set of certain organisations which commission research, as there has been for years, but they have proliferated since IDS became dependent on aidpolicy-related funding: foundations, think-tanks and non-governmental organisations. The reason that they are increasingly commissioning policy research is that core functions of the bureaucracy in relation to policy are either underdeveloped and/or have been outsourced and subcontracted. Some argue that these core functions are being commodified like any other field of accumulation. The commodification of policy involves the processes of authorising the agenda, of law and procedure, the raising of tax, the sourcing of loans and aid and the performing of access roles. Commodified policy is thought to result both in a decline in the quality of evidence used in policymaking and in an increase in the difficulty with which the residual bureaucracy processes and interprets the outcome of this process (Leys 2006). It is then not just policy research but the research in the other cells that is affected. 
The third cell, the lower line of the matrix, contains reflexive research. Within the academy it consists of critical and historical research. The Bangladesh Roundtable sought to problematise the consultancy and contract culture in the production of knowledge. Pakistan and India problematised both the role of aiddriven research in development and the role of aiddriven development in research. Lawrence Haddad called for a critical understanding of the simultaneous coexistence of opposite forces. He gave the example of institutional convergence in contrast with - or happening at the same time as - the retreat to the idiosyncrasies of identity. Shalmali Guttal spoke about the need to scrutinise how hegemonic institutions neutralise and perhaps depoliticise all the challenges that have been aimed at them, and both Mike Edwards and José Antonio Ocampo spoke about the structures of incoherence that are built into the politics of the global system. That is not as long a list as the list of demands for professional research from South Asia but I wouldn't say it was 'warm water'. If you leap into such lakes the water is cold - those are quite hard subjects to address.

I have also noticed the absence of calls for new theory. It seems that the Roundtables and the conference have acute theory fatigue. One problem with theory is that not all theory requires a 'problem and solution' framing. José Antonio Ocampo certainly laid out his argument in a problem-solving paradigm. He used an institutional neo-Keynesian development economics and microeconomic framework. Even that led to what was something of an aside about the structural incoherence of the UN. That is quite a big aside.

How can you have a solution, even experimental solutions, unless you have a theory, or theories?

For me the big elephant in the 'critical' cell of the development studies knowledge matrix is the taboo word 'capitalism'. It is not to be found in the newly published booklet from the IDS Knowledge Services, A Good Place to Start (2006). Even 'markets' are not there, nor is the term 'labour'. Polanyi's swinging pendulum is not swinging towards markets; it is swinging towards deregulated capitalism. Development studies was long concerned to understand the specificities of capitalism in order to shape, to defend or to better incorporate the capitalist peripheries; and to regulate the damage caused by capitalism. For several decades, development studies consisted of a body of people who rejected the idea that the only pathway was a mindless incorporation into the global capitalist system. It was a group of scholars which also rejected the military-developmental embrace. It is especially important to reject that taboo and revisit the theories that name the ' $\mathrm{C}$ ' word not the least because the recent era of global development has unleashed a global capitalism which not only impoverishes as it creates wealth but also is going to cause, which is causing, climate change.

It is impossible to think creatively about Wolfgang Sachs' ideas about contraction and convergence without an analysis of the relationship between the compulsion of capitalist growth and the energetics of that growth. Climate change was also something that was neglected in the South Asian Roundtables. 'The environment' was grouped with gender at this conference; Lawrence Haddad describes climate change in his overview as an 'issue bubble which doesn't travel'. It's very definitely 'not our department' as Werner von Braun said in the Tom Lehrer song. Perhaps it's not our department, not only because of the theoretical problems it poses, but also because we are a dirty and polluting kind of subject, a bit like big science. We are dirty and polluting because of our compulsion to travel.

Some of the most marginalised voices in development studies are those of the dead. Kari Levitt spoke about the counterfactuals Dudley Seers might have triggered, ${ }^{2}$ and if he had remained alive, Gordon White (who lies in Brighton's Bear Road Cemetery, just downhill from Hans Singer) would have made sure that the politics of global environment and global climate change would have been central to IDS now.

The last cell in the table is public research, about which Mike Edwards has spoken so passionately. All of the Roundtables had reasons to value it. At the IDS40 meeting, Adebayo Olukoshi and Shalmali Guttal both called for it. Mike Edwards' argument was focused on the USA but is also relevant to the UK. Research in the 'public interest' is being called for everywhere. But who is paying for it? Think-tanks and development NGOs have developed their own research wings. It is these units rather than academics which write the opinion pieces and letters to newspapers on public interest matters. Who is allowing us the freedom to do it? The Human Development and Capability Association has commissioned a neat piece of research into how Hayek 
and the neoliberals quite deliberately disseminated neoliberalism throughout the academy and political elites (Ritchie 2004). Likewise, a massive controversy was triggered by the article by Mearsheimer and Walt (March 2006) in The London Review of Books on the Israel lobby who framed their polemic by a concern for strategies which persuade governments to do things which are not obviously in their own interests.

The concepts of 'problem' and 'solution' here are no easy thing if development is conceived as a political project. We have to conceive 'solutions' politically. It is not easy to do this now from research institutions.

Last but not least, the public side of development studies is the public of young people, just as taboo as capitalism. The seven-minute video clip from the IDS alumni which was shown at the conference made a crucial point. Good research is needed and justified in order to understand our world, in order to teach, and in order that young people learn about our world, so that they will go out and act with reason, and will have reasons not to do certain things. This role is under threat. Rammanohar Reddy, the new editor of the Economic and Political Weekly, visited Oxford in September 2006 and spoke about the crisis in social science in Indian universities. There is a sharp decline in quality, due to the brain drain and to

\section{Notes}

1 I was married to Gordon White, Professor of Politics at IDS until his untimely death in 1998

2 The IDS40 conference included a memorial meeting to commemorate the life of Hans Singer (1910-2006), at which Kari Levitt (McGill University) also spoke about the work of Dudley Seers, first Director of IDS.

\section{References}

Burawoy, Michael (2005) Forging Public Sociologies on National, Regional and Global Terrains, E-Bulletin of the International Sociological Association 2: 42-52, http://sociology.berkeley.edu/faculty/ burawoy/workingpapers.htm

Leys, Colin (2006) 'The Cynical State', The Socialist State 2006, http://socialistregister.com/sample/1

Mearsheimer, John and Walt, Stephen (2006) 'The Israel Lobby', London Review of Books 28.6, March, www.Irb.co.uk/v28/n06/mearO1_html rural students having the fortune to gain access to tertiary education but not having the language skills either to learn or to teach as well as does India's elite. It is also due to massive underfunding of the university sector, which itself is a product of the tax evasion which strangles the state. Mike Edwards addressed the crisis in social science in the USA, which is not due to the same factors as in India. Nonetheless, it seems to me extraordinarily strange that it is not possible to justify research in terms of its contribution to understanding, teaching and learning. The funders clearly do not want us to do this. But resisting this and finding ways to conduct critical and public development research is far easier to say than to do.

I conclude that development as a project of 'catchup' is dead in the water; for if it is based on fossil fuel it will destroy the planet, a new context for an aspirational project is not yet born, and we are working in an era of flux. Thandike Mkandawire, speaking at the QEH anniversary conference, stressed the potential contribution to this ferment of ideas, intellectuals, institutions and universities 'in the South'. IDS has suggested 'in the East' as well. I am certain he would have complemented IDS on pulling off an extremely brave and original project, overwhelmingly 'in the South' - and so also do I!
Ritchie, Angus (2004) 'Winning the War of Ideas: Lessons from the Neo-Liberals', Briefing for the Human Development and Capabilities Association working group expert roundtable at King's College, Cambridge, November, www.theology-centre.org/ Winning\%20the\%20War\%20of\%2Oldeas\%5B1\%5D.rtf 